\title{
Frequent long-distance gene flow in a rare temperate forest tree (Sorbus domestica) at the landscape scale
}

\author{
U Kamm ${ }^{1,2}$, P Rotach ${ }^{2}$, F Gugerli ${ }^{1}$, M Siroky ${ }^{1,2}$, P Edwards ${ }^{3}$ and R Holderegger ${ }^{1}$

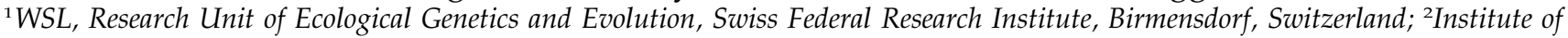 \\ Terrestrial Ecosystems, ETH Zurich, Zurich, Switzerland and Institute of Intergrative Biology, ETH Zurich, Zurich, Switzerland
}

\begin{abstract}
Precise empirical data on current gene flow by pollen, both with respect to distance and abundance, is crucial to understand whether habitat fragments are functionally connected. Based on a large-scale inventory $\left(\approx 100 \mathrm{~km}^{2}\right)$ in which all individuals of a naturally scattered forest tree (Sorbus domestica) were mapped, we inferred current gene flow by pollen using genetic paternity analysis. We detected an extensive network of effective pollen transfer. Although short pollen flow distances were most abundant, $10 \%$ of the assigned pollen donors were more than $2 \mathrm{~km}$ away from their female mating partners, and $1.8 \%$ were even at a distance of $12-16 \mathrm{~km}$. This latter pollen flow shows that current long-distance gene flow over a
\end{abstract}

fragmented landscape clearly occurs. Pollen dispersal was well described by a fat-tailed inverse curve. Using parentage analysis of established trees, maternally inherited chloroplast markers and diameter at breast height measurements as an indicator of individual tree age, we were able to infer regular seed dispersal distances over several hundred metres up to more than $10 \mathrm{~km}$. We conclude that in temperate, insect-pollinated and animal-dispersed tree species such as $S$. domestica, fragmented subpopulations are functionally connected by gene flow through both pollen and seed.

Heredity (2009) 103, 476-482; doi:10.1038/hdy.2009.70; published online 5 August 2009

Keywords: functional connectivity; landscape genetics; long-distance pollen flow; paternity analysis; pollen dispersal; seed dispersal

\section{Introduction}

Obtaining reliable measures of long-distance gene flow (LDGF) is relevant in various ecological contexts, including studies of habitat fragmentation (Sork and Smouse, 2006), the spread of invasive species (Dunphy and Hamrick, 2005), range shifts due to climatic change (Reusch and Wood, 2007) and the introduction of genetically modified crops (Williams and Davis, 2005). Thanks to improved molecular, genetic and statistical methods such as parentage analysis (Sork et al., 1999), it has lately become easier to directly investigate patterns of current gene flow. In accordance, gene flow distances far exceeding those reported in traditional ecological experiments (Ellstrand, 1992) have recently been demonstrated for several woody species, among them many tropical, insect-pollinated and animal-dispersed trees (White et al., 2002; Lowe et al., 2005; Ward et al., 2005; Hardesty et al., 2006).

Despite the potential of genetic approaches to investigate LDGF, most empirical studies of tree populations have been limited in scope, either because they were restricted to relatively small areas within continuous

Correspondence: $\mathrm{Dr}$ U Kamm, Berne University of Applied Sciences, Swiss College of Agriculture, Forest Ecology, Laenggasse 85, CH-3052 Zollikofen, Switzerland.

E-mail: urs.kamm@bfh.ch

Received 21 November 2008; revised 13 May 2009; accepted 26 May 2009; published online 5 August 2009 populations (Ward et al., 2005) or because they evaluated current patterns of gene flow among small forest fragments (Lowe et al., 2005; Bacles and Ennos, 2008). The first type of study provides detailed information on current gene flow patterns at comparatively small spatial scales. As these direct measures of gene flow are restricted by the spatial extent of the empirical data (Nathan, 2006), the probability of dispersal of pollen or seed to larger distances is usually extrapolated using appropriate mathematical models (that is, dispersal kernels; Oddou-Muratorio et al., 2006). However, such models are notoriously unreliable in characterizing the tail of the dispersal curve, that is, the part of the curve representing LDGF. In the second approach, individual cases of long-distance dispersal are detected, but it is impossible to quantify the distances over which such events occur, unless all fragments in a given landscape are studied (Bacles and Ennos, 2008). Corresponding studies also often find a weak relationship between siring success and the distance between mating partners and thus question that most pollinations occur among nearest neighbors (Kramer et al., 2008).

Considering the above limitations, spatially explicit data on effective long-distance pollen movement and seed dispersal are needed on the landscape scale to reliably quantify the distance and frequency of LDGF. Such spatially explicit data on effective long-distance pollen and seed dispersal are needed to understand functional connectivity among forest fragments. A better empirical basis on functional connectivity by gene flow 
within landscapes would substantially contribute to the open discussion on the paradox of forest fragmentation genetics (Kramer et al., 2008).

The aim of this study was to directly investigate current gene flow by pollen as well as recent gene flow by seed (that is, one generation earlier) at the landscape scale using parentage and paternity analysis. Parentage analysis, the currently most effective approach for the precise description of current pollen flow and seed dispersal patterns, requires that all potential parents of open-pollinated progenies within a study area are mapped, sampled and genotyped (Chase et al., 1996). When aiming at data on gene flow distances at the landscape level, study areas are comparably large, which leads to considerable effort for identifying all parents in the field and genotyping them in the laboratory (Manel et al., 2003). Species that naturally occur in low densities are particularly suitable for this purpose, as it is realistic to map and genotype all potential parents in a landscape.

By relying on a well-known population of the naturally scattered tree Sorbus domestica (L.) monitored for more than 20 years, we could be reasonably certain of having located all mature trees of this species in a study area of over $100 \mathrm{~km}^{2}$ (Figure 1). Maximum distances among potential mates were up to $25 \mathrm{~km}$. Thus, the data set offered an extraordinary framework to investigate the functional connectivity of a forest tree, both through gene flow by pollen and seed. We asked the following questions: (1) To what extent are the individuals of the insect-pollinated $S$. domestica genetically connected by current pollen transfer? (2) Which mathematical function adequately describes the pollen dispersal curve detected? (3) Is there evidence for recent long-distance seed dispersal?

\section{Materials and methods}

\section{Study species}

The service tree, Sorbus domestica L. (Rosaceae), naturally occurs in low densities in Central Europe (Barengo et al., 2001). It is an insect-pollinated, fleshy fruited, temperate forest tree. Like other woody species of the Rosaceae, its white hermaphroditic flowers attract a large variety of generalist pollinators such as Diptera, bees and bumblebees (Raspé et al., 2000; Oddou-Muratorio et al., 2006). The stamens mature slightly before the styles, but flowering is not synchronous within corymbs and individual trees, allowing for sequential visits by pollinators. Observations of flowering phenology of the closely related $S$. torminalis showed that individual trees differ in the flowering period, but that most if not all trees within populations overlap in flowering to a certain degree (Hoebee et al., 2007). We assumed that individuals of $S$. domestica could thus potentially mate with each

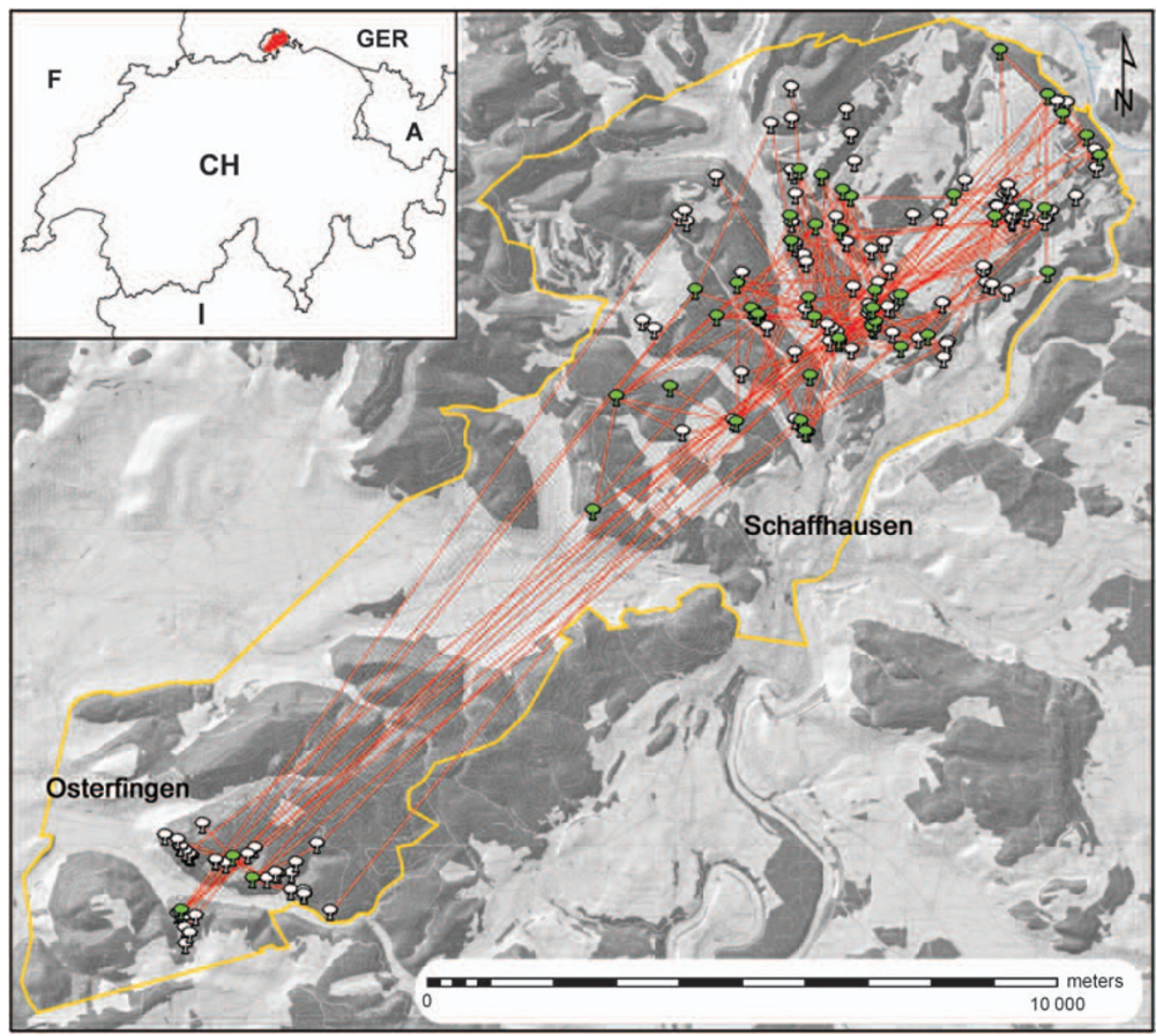

Figure 1 Current gene flow patterns by pollen in Sorbus domestica at the landscape scale in Schaffhausen, Switzerland. The yellow line delimits the study area $\left(>100 \mathrm{~km}^{2}\right)$ within which all $S$. domestica individuals were genotyped (tree symbols). Forest areas are displayed in dark grey, and green tree symbols indicate mother trees from which offspring was genetically analysed. Red lines connect mating partners identified by paternity analysis and thus represent current gene flow events by pollen. The inset gives the position of the study area (red) within Switzerland (CH; neighbouring countries: GER: Germany; A: Austria; I: Italy; F: France). 
other. A characteristic that $S$. domestica probably shares with other woody Rosaceae is a gametophytic selfincompatibility system (Raspé and Kohn, 2002; Holderegger et al., 2008). However, self-incompatibility systems may break down when pollination is delayed or during periods of adverse weather conditions (De Nettancourt, 2001; Garcia et al., 2005), and individual trees may therefore exhibit substantial selfing rates (Oddou-Muratorio et al., 2006; Hoebee et al., 2007). Sorbus domestica is representative of a group of insect-pollinated, fleshy fruited and naturally scattered rare forest tree species of Central Europe such as Pyrus pyraster, Malus silvestris, Prunus mahaleb or S. torminalis (Barengo et al., 2001).

\section{Study area and sampling}

Within the study area in the Canton of Schaffhausen in northern Switzerland, Sorbus domestica occurs as scattered individuals within extensive areas of forest dominated by Fagus sylvatica. We based our study on a comprehensive inventory compiled over the past 20 years, in which all known trees of $S$. domestica had been recorded for the purpose of conservation and seed collection. We supplemented this inventory with additional information on tree positions from regional forest inventories and our own systematic survey of the area. We were thus confident that the vast majority if not all reproductive individuals of $S$. domestica in the study area had been located. We verified all reported locations and mapped them by using a hand-held GPS receiver. The trees varied in their degree of spatial isolation from other trees of $S$. domestica. At a larger scale, they formed two fairly distinct subpopulations (Schaffhausen and Osterfingen; Figure 1). Densities were 0.042 individuals per hectare for Schaffhausen and 0.138 individuals per hectare for Osterfingen. Our study area adjoined the Swiss-German border (Figure 1). In adjacent Germany, however, $S$. domestica is supposed to be absent or at least very rare, probably because of historically different forest management strategies in the two countries.

We collected fresh leaves or buds from all known 189 $S$. domestica trees and determined their diameters at breast height. We visited fruiting individuals up to three times during September-October to collect fruits. Leaves were dried in silica gel, whereas fruits and buds were stored at $-20^{\circ} \mathrm{C}$. Over all, the fruit set of most trees was low. We thus only used maternal trees from which we were able to collect at least 25 fruits $(N=49)$.

\section{DNA extraction and microsatellite genotyping}

We extracted total genomic DNA following a slightly modified DNeasy plant kit protocol (Qiagen, Hilden, Germany). For adult trees, DNA was isolated from $15 \mathrm{mg}$ of dried leaf material or $50 \mathrm{mg}$ of frozen bud tissue. We also extracted DNA form lyophilized embryos and cotyledons that had been carefully excised from seeds $(N=1183$ seeds; one seed per fruit).

Nuclear microsatellite markers (nSSRs) were transferred from closely related woody Rosaceae species. We tested 28 nSSR primer pairs designed for Malus (Gianfranceschi et al., 1998; Liebhard et al., 2002), Pyrus (Yamamoto et al., 2002a, b) and Sorbus (Oddou-Muratorio et al., 2001; Robertson et al., 2004). PCR products were screened for polymorphism on high-resolution Spreadex gels (Elchrom, Cham, Switzerland). Finally, we chose nine variable nSSR markers exhibiting highly reproducible amplification patterns (Table 1). Primers were combined in two multiplex-PCR amplifications comprising five and four primer pairs, respectively. Each reaction volume of $10 \mu \mathrm{l}$ contained $0.5 \mu \mathrm{l}$ template DNA $\left(\approx 4 \mathrm{ng} \mu \mathrm{l}^{-1}\right), 5 \mu \mathrm{l}$ Multiplex-Master mix (Qiagen) and $1 \mu \mathrm{l}$ of each primer $(2 \mu \mathrm{M})$. PCRs were performed on PTC100 thermocyclers (MJ Research, Waltham, MA, USA) starting with initial denaturation at $95^{\circ} \mathrm{C}$ for $15 \mathrm{~min}$, running 30 cycles with $94^{\circ} \mathrm{C}$ for $30 \mathrm{~s}, 50$ or $60^{\circ} \mathrm{C}$ for $90 \mathrm{~s}$ (depending on the multiplex reaction; Table 1) and ending with a final extension at $72^{\circ} \mathrm{C}$ for $30 \mathrm{~min}$. Amplified fragments were analysed on an ABI 3100Avant capillary sequencer (Applied Biosystems, Foster City, MA, USA). Fragment sizes were assessed using GENOTYPER 3.5 (Applied Biosystems) relative to a ROX $400 \mathrm{HD}$ size standard (Applied Biosystems). Goodnessof-fit Hardy-Weinberg equilibrium tests and estimates of the frequency of null alleles were carried out using CERVUS 2.0 (Marshall et al., 1998).

Table 1 Characteristics of nine nuclear microsatellite loci in Sorbus domestica with primer sequence, number of alleles observed and their size range, annealing temperature $\left(T_{\mathrm{a}}\right)$ and corresponding reference

\begin{tabular}{|c|c|c|c|c|c|}
\hline Locus & Primer sequence $\left[5^{\prime}-3^{\prime}\right]$ & Number of alleles & Size range $[b p]$ & $\mathrm{T}_{a}\left[{ }^{\circ} \mathrm{C}\right]$ & Reference \\
\hline MSS5 & $\begin{array}{l}\text { F:CCСCAACAACATTTTTCTCC } \\
\text { R:CCTCTCGCTCTTTGCСTCT }\end{array}$ & 5 & $117-127$ & 60 & Oddou-Muratorio et al. (2001) \\
\hline MSS16 & $\begin{array}{l}\text { F:CTCCCCTTGTGTGATGCC } \\
\text { R:TTGCCCTCAAAGAATGCC }\end{array}$ & 4 & $143-161$ & 60 & Oddou-Muratorio et al. (2001) \\
\hline CH01h10 & $\begin{array}{l}\text { F:TGCAAAGAAGGTAGATATATGCCA } \\
\text { R:AGGAGGGATTGTTTGTGCAC }\end{array}$ & 11 & $105-136$ & 60 & Gianfranceschi et al. (1998) \\
\hline CH01h01 & $\begin{array}{l}\text { F:GAAAGACTTGCAGTGGGAGC } \\
\text { R:GGAGTGGGTTTGAGAAGGTT }\end{array}$ & 5 & $87-137$ & 60 & Gianfranceschi et al. (1998) \\
\hline $\mathrm{CH} 02 \mathrm{c} 09$ & $\begin{array}{l}\text { F:TTATGTACCAACTTTGCTAACCTC } \\
\text { R:AGAAGCAGCAGAGGAGGATG }\end{array}$ & 6 & $223-243$ & 60 & Liebhard et al. (2002) \\
\hline BGT23b & $\begin{array}{l}\text { F:CACATTCAAAGATTAAGAT } \\
\text { R:ACTCAGCCTTTTTTTCCCAC }\end{array}$ & 4 & 190-196 & 50 & Yamamoto et al. (2002b) \\
\hline $\mathrm{CH} 02 \mathrm{~B} 03 \mathrm{~b}$ & $\begin{array}{l}\text { F:ATAAGGATACAAAAACCCTACACAG } \\
\text { R:GACATGTTTGGTTGAAAACTGG }\end{array}$ & 7 & 87-103 & 50 & Gianfranceschi et al. (1998) \\
\hline MS14H03 & $\begin{array}{l}\text { F:CGCTCACCTCGTAGACGT } \\
\text { R:ATGCAATGGCTAAGCATA }\end{array}$ & 9 & $162-181$ & 50 & Liebhard et al. (2002) \\
\hline $\mathrm{CH} 02 \mathrm{~d} 08$ & $\begin{array}{l}\text { F:TCCAAAATGGCGTACCTCTC } \\
\text { R:GCAGACACTCACTCACTATCTCTC }\end{array}$ & 11 & $237-265$ & 50 & Liebhard et al. (2002) \\
\hline
\end{tabular}

Abbreviations: F: forward primer; R: reverse primer. 


\section{Current pollen flow}

Mating patterns of individual mother trees were determined in a paternity analysis of their openpollinated offspring. Paternity was assigned using the maximum likelihood-based method (Meagher, 1986) implemented in CERVUS 2.0 (Marshall et al., 1998). The program uses simulation-based data to assign paternity at a specified significance threshold. To run simulations, we used the following parameters: 10000 simulated mating events; minimum number of matching loci equals eight; error rate of zero (Slate et al., 2000, Slavov et al., 2005; note that using an error rate of 0.01 had no relevant effects on paternity assessment); all adult trees as candidate parents $(N=167$; each clonal cohorts were counted as single genetic individuals), complete sampling of candidate parents; all loci typed for all samples. We applied a 95\% significance threshold to ensure valid assignment, thus accepting missing cases of true paternity. Special attention was given to long-distance pollen flow events between the two subpopulations. Here, we conservatively used a $100 \%$ significance threshold.

We used different curve estimation regression models (SPSS 14.0, SPSS, Chicago, and TABLECURVE 2D, SYSTS, Richmond) to determine the function that best fitted the empirical data on pollen flow with increasing geographical distance.

\section{Recent seed dispersal}

To obtain information about the distances between maternal trees and their established progeny (that is, seed dispersal across one generation), we determined the maternally inherited (Raspé, 2001) cpDNA haplotypes of all adult $S$. domestica trees in our study area. Screening for variation was performed using 18 universal cpDNA primer pairs described in Demesure et al. (1995), Dumolin-Lapègue et al. (1997), Grivet et al. (2001) and Sang (1997), which were well distributed over the large single copy (LSC) region (Grivet et al., 2001), on 18 S. domestica individuals distributed over the whole study area. Amplification was done in $20 \mu \mathrm{l}$ volumes containing $1.0 \mu \mathrm{l}$ template DNA $\left(\approx 4 \mathrm{ng} \mu \mathrm{l}^{-1}\right), 10 \mu \mathrm{l}$ Multiplex-Master Mix (Qiagen) and $0.1 \mu \mathrm{l}$ of each primer $(2 \mu \mathrm{M})$. PCR amplifications were performed on PTC-100 thermocyclers (MJ Research), using initial denaturation at $95^{\circ} \mathrm{C}$ for $15 \mathrm{~min}, 34$ cycles with $94^{\circ} \mathrm{C}$ for $30 \mathrm{~s}, 48-60^{\circ} \mathrm{C}$ (depending on the given primer) for $90 \mathrm{~s}$ and $72{ }^{\circ} \mathrm{C}$ for $3 \mathrm{~min}$, followed by a final extension at $72^{\circ} \mathrm{C}$ for $10 \mathrm{~min}$. Fragments were amplified from 13 primer pairs, and the PCR products were then screened for restriction fragment length polymorphisms using 14 restriction endonucleases. PCR products $(1 \mu \mathrm{l})$ were digested in $10 \mu \mathrm{l}$ reaction volumes for $3 \mathrm{~h}$ with $1 \mathrm{U}$ of restriction enzyme at $37^{\circ} \mathrm{C}$ in an oven. Restriction fragments were separated by electrophoresis on $2 \%$ agarose gels in $1 \times \mathrm{TBE}$ buffer at $110 \mathrm{~V}$ for $2 \mathrm{~h}$. For visualization, gels were stained with ethidium bromide and photographed under UV (UVP, Upland, CA, USA). We only found two different cpDNA haplotypes, with frequencies of 0.114 and 0.886 , respectively ( $\operatorname{trnK}$ [ [tRNA-Lys (UUU) exon 1] and $t r n \mathrm{~K}$ [tRNA-Lys (UUU) exon 2], RE AluI; for primers described in Demesure et al., 1995). In addition, we tested the universal cpDNA microsatellite primers described by Deguilloux et al. (2003), but could not find any variation.
For trees from subpopulation Schaffhausen (Figure 1) with the rare cpDNA haplotype, we performed a parentage analysis using the nuclear microsatellite data to assign the most likely parents (CERVUS; significance level 80\%). If the most likely parent had the same rare cpDNA haplotype as the individual tested and also exhibited a larger diameter at breast height (as rough indicator of tree age), it was considered to be the mother tree and, hence, the source plant of seed dispersal.

\section{Results}

We detected 62 alleles in the nine nuclear microsatellite markers, with four to eleven alleles per locus (Table 1). Two private alleles, each with a single occurrence, were detected in the offspring. All loci showed diploid banding patterns, and Mendelian inheritance was observed when genotypes of offspring and corresponding mothers were compared. One locus (MSS 16) showed evidence for the occurrence of a null allele (null allele frequency estimated by CERVUS: 0.0104, $P<0.01$ ). However, mother-offspring comparisons resulted in no obvious signs of null alleles at this locus, and it was therefore retained in the analysis.

CERVUS analysis resulted in a high exclusion probability of 0.993 . In accordance, $62.9 \%(N=744)$ of the offspring could be assigned with a high confidence of $\geqslant 95 \%$ to a single pollen donor. For $27.4 \%(N=324)$ of the offspring, several potential fathers were found (that is, unassigned gene flow within the population), whereas for $9.7 \%(N=115)$, no matching father could be found. In view of the exhaustive sampling of the adult trees and the above mentioned high exclusion probability, these non-matching offspring genotypes were attributed to pollen immigration (Garcia et al., 2005). Using these data, we assessed the selfing rate per mother tree and the straight-line distances between mothers and unambiguously identified father trees. Overall selfing rate was $33.5 \%(N=249)$, but variation in selfing rates was considerable, with individuals having no selfed offspring (34.7\% of mothers) to individuals with over $80.0 \%$ of selfed seeds $(8.0 \%$ of mothers).

The mean pollen flow distance was $1.2 \mathrm{~km}(N=495)$, but the shape of the frequency distribution of pollen dispersal was leptokurtic, with a rapid decrease within the first $200 \mathrm{~m}$, indicating a predominance of nearneighbour gene exchange (Figure 2). However, a surprisingly high proportion $(>33 \%)$ of pollen donors were located at a distance of more than $1 \mathrm{~km}$ from the mother trees (Figure 2). We also detected 13 long-distance pollen flow events between the two subpopulations at distances of $12-16 \mathrm{~km}$ (Figure 1), six of them being supported at a $100 \%$ level of statistical confidence.

Pollen dispersal was well described by a simple inverse curve $\left(y=-0.067+2551.54 / x ; R^{2}=0.985\right)$, with a long tail (Figure 2). Alternative curve estimation models such as power $\left(R^{2}=0.843\right)$ or exponential models $\left(R^{2}=0.485\right)$ less fitted the pollen dispersal data.

We could only infer 10 unambiguous events of recent seed dispersal (Figure 3). These seed dispersal events covered distances between $12 \mathrm{~m}$ and $12357 \mathrm{~m}$, with most dispersal events at distances between $1-2 \mathrm{~km}$. 


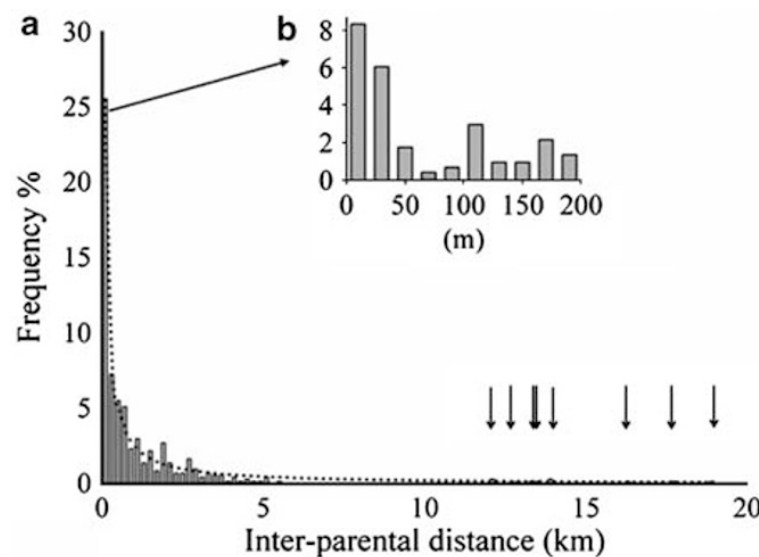

Figure 2 Frequency distribution of current pollen flow in Sorbus domestica (grey bars). (a) Frequency distribution in 200-m distance classes. The dotted line represents the best fitting curve $(y=-0.0674+2551.54 / x)$, and the arrows indicate long-distance events of pollen flow. (b) Inset for distances of $0-200 \mathrm{~m}$ in $20-\mathrm{m}$ distance classes.

\section{Discussion}

Our results show that, despite the heterogeneous landscape and the low density of S. domestica in the study area, most adult trees formed part of an extensive network of pollen flow spanning deep valleys and large unforested areas comprising intensively used agricultural land and built areas (Figure 1). Interestingly, most of the offspring for which no matching father could be assigned were from mothers growing close to the northern border of the study area (data not shown). In contrast to our survey, this result indicated that at least some unknown $S$. domestica adult individuals grow outside our study area in adjacent Germany.

The average pollination distance of about $1.2 \mathrm{~km}$ for 495 outcrossed offspring assigned to single pollen donors was larger than those that have been reported for closely related temperate (Oddou-Muratorio et al., 2005; Hoebee et al., 2007) or tropical tree species (Ward et al., 2005). However, the maximum distance of pollen flow of $16 \mathrm{~km}$ is, to our knowledge, the largest distance that has been directly measured so far. These large pollen flow distances reflected the large size of our study area, illustrating the limited value of estimates of average pollen flow distances derived from spatially restricted studies. Based on considerations of tree density, it has been deduced that gene flow by pollen in tropical fig species should occur over similar distances as reported here (Nason et al., 1998). However, unlike S. domestica, tropical figs have highly specialized insect pollinators that have evolved the ability to locate their widely spaced host plants in tropical rainforest (Ollerton et al., 2006). In contrast, $S$. domestica relies on a wide spectrum of generalist pollinators (Raspé et al., 2000). We conclude that at least some pollinators that visit $S$. domestica locate trees of the same species across large areas of open habitat. Several insect pollinators are indeed known to cross large patches of unsuitable habitat (Steffan-Dewenter and Kuhn, 2003), suggesting that foraging distances of insects may have generally been underestimated. For $S$. domestica, the most likely long-distance pollen vectors

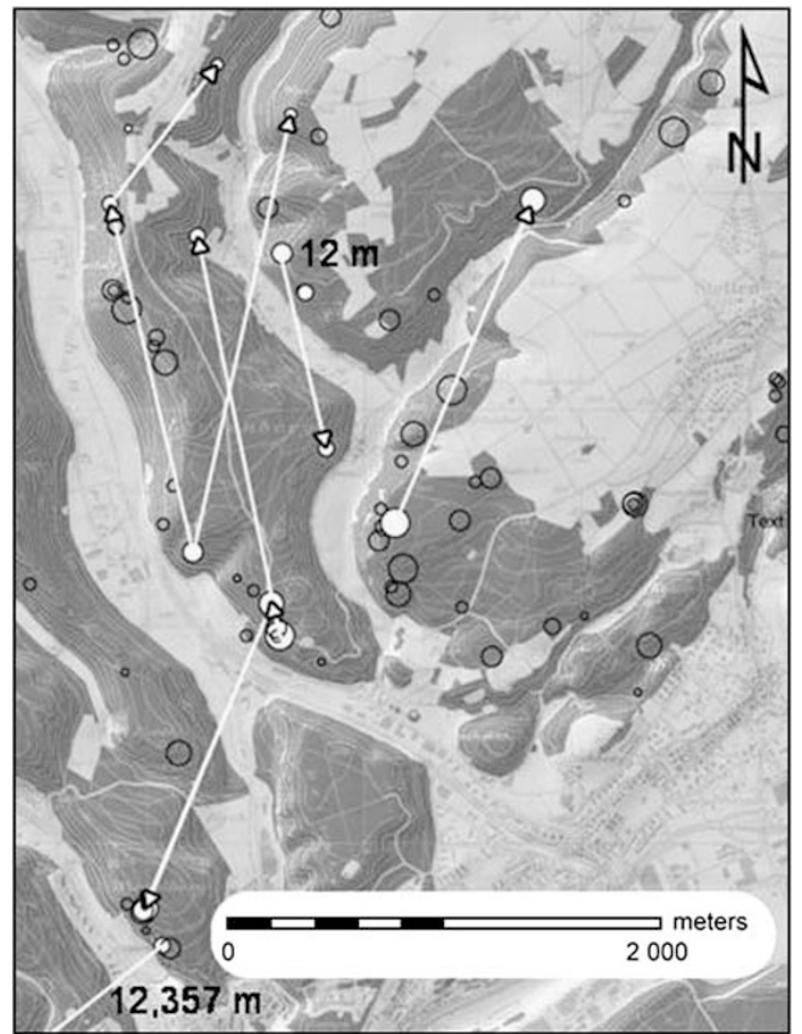

Figure 3 Recent gene flow by seed in Sorbus domestica at the landscape scale in Schaffhausen, Switzerland. White circles indicate trees with the rare cpDNA haplotype (all trees with the rare haplotype from subpopulation Schaffhausen are shown), whereas open circles show trees having the frequent cpDNA haplotype. Circle sizes are proportional to tree diameters at breast height. Arrows represent inferred recent events of gene flow by seed. Numbers indicate the shortest and the longest dispersal event. Note that this is a zoom-in from Figure 1.

are bumblebees and honey bees, as these insects are known to have large foraging ranges (Kreyer et al., 2004).

The shape of the curve describing the frequency distribution of pollen flow events with increasing geographical distance was consistent with other studies on pollen flow in trees also reporting leptokurtic pollen dispersal curves with fat tails (Oddou-Muratorio et al., 2005). Accordingly, modelling approaches for several forest tree species strongly indicated that fat-tailed pollen dispersal curves are much more likely than thin-tailed pollen dispersal curves (Austerlitz et al., 2004). However, although most published pollen dispersal curves relied on extrapolation from observations of pollen flow over rather short distances, our dispersal curve was empirically also supported for larger distances. The existence of a fat tail is significant because it implies that even isolated trees receive pollen from a genetically diverse donor pool (Klein et al., 2006). Nonetheless, the total number of foreign pollen received by isolated trees is likely to be small, which might explain the high selfing rates observed in some trees (U Kamm unpublished data). Several woody Rosaceae are known to exhibit weak self-incompatibility which breaks down if crosspollination is delayed (Garcia et al., 2005).

Seed dispersal is another process enabling plants to move genes in space. As in the case of pollen, recent 
molecular genetic studies have demonstrated the importance of long-distance dispersal of seeds (Bacles et al., 2006; Hardesty et al., 2006) for colonization as well as for maintaining functional connectivity of spatially isolated populations. In the case of the wind-pollinated and wind-dispersed tree Fraxinus excelsior, seed dispersal was shown to be more effective than pollen dispersal in maintaining functional connectivity (Bacles et al., 2006).

Long-distance dispersal of seed is supported by studies using both direct (Godoy and Jordano, 2001) and indirect (Mohanty et al., 2002) genetic methods in temperate forest trees with fleshy fruits. As shown here, it seems that $S$. domestica seeds are regularly dispersed to distances of several hundred meters. Most dispersal events observed were along forested hill ranges, but also traversed valleys between inferred mother-offspring pairs (Figure 3). In view of the high mobility of seed vectors such as birds and large mammals (for example, roe deer, wild boar; Myers et al., 2004), we assume that the seed dispersal distances of up to $12 \mathrm{~km}$ detected in our study probably do not represent the maximum distances that may occur.

Although the extensive gene flow network by pollen detected in $S$. domestica enables the formation of a genetically diverse seed pool, natural regeneration in the study area was low or even absent (U Kamm, personal observation). This was probably due to low fruit production combined with a low availability of suitable regeneration niches. In central Europe, the habitat suitable for the recruitment of light-demanding forest species such as S. domestica has declined as forests have become generally older and darker over the past 100 years (Wohlgemuth et al., 2002). In addition, the low density of pollen donors, reflected by generally higher selfing rates of isolated trees (Larson and Barrett, 2000), was probably responsible for low seed production in our study species. Indeed, Aguilar et al. (2006) have argued that the most common proximate cause of reproductive impairment in fragmented habitats may be pollination limitation. In our study area, S. domestica produced genetically diverse offspring, but because suitable habitat patches for regeneration were widely scattered, the few seeds produced may be insufficient to maintain the population.

The extensive network of pollen flow revealed in this study has implications for conservation. First, S. domestica is representative for several rare forest trees in Central Europe that are insect-pollinated, fleshy fruited and persist as scattered individuals in managed high forests. As well as securing natural regeneration, management strategies for such species should aim to maintain the number of local populations, even if they appear to be small and geographically isolated, as they may form part of an interbreeding network of stands. Second, in assessing the effectiveness of current programmes to increase habitat connectivity, we need to shift from descriptive studies of structural habitat networks to a more quantitative analysis of their functional connectivity (Nathan, 2005; Holderegger and Wagner, 2008).

\section{Acknowledgements}

This work would not have been possible without decades of fieldwork undertaken by scientists of the former chair of silviculture at the Swiss Federal Institute of Technology, Zürich, mapping the occurrences of $S$. domestica in the Canton of Schaffhausen. We also thank two anonymous referees for helpful suggestions on the article. The study was supported by a research grant $(\mathrm{TH}-33 / 04-2)$ of the Swiss Federal Institute of Technology in Zurich.

\section{References}

Aguilar R, Ashworth L, Galetto L, Aizen MA (2006). Plant reproductive susceptibility to habitat fragmentation: review and synthesis through a meta-analysis. Ecol Lett 9: 968-980.

Austerlitz F, Dick C, Dutech C, Klein EK, Oddou-Muratorio S, Smouse $P$ et al. (2004). Using genetic markers to estimate the pollen dispersal curve. Mol Ecol 13: 937-954.

Bacles CFE, Ennos RA (2008). Paternity analysis of pollenmediated gene flow for Fraxinus excelsior L. in a chronically fragmented landscape. Heredity 101: 368-380.

Bacles CFE, Lowe AJ, Ennos RA (2006). Effective seed dispersal across a fragmented landscape. Science 311: 628.

Barengo N, Rudow A, Schwab P (2001). Förderung seltener Baumarten auf der Schweizer Alpennordseite. BUWAL: Bern.

Chase MR, Moller C, Kesseli R, Bawa KS (1996). Distant gene flow in tropical trees. Nature 383: 398-399.

De Nettancourt D (2001). Incompatibility and Incongruity in Wild and Cultivated Plants. Springer: Berlin.

Deguilloux FM, Dumolin-Lapègue S, Gielly L, Grivet D, Petit RJ (2003). A set of primers for the amplification of chloroplast microsatellites in Quercus. Mol Ecol Notes 3: 24-27.

Demesure B, Sodzi N, Petit RJ (1995). A set of universal primers for amplification of polymorphic non-coding regions of mitochondrial and chloroplast DNA in plants. Mol Ecol 4: 129-131.

Dumolin-Lapègue S, Pemonge MH, Petit RJ (1997). An enlarged set of consensus primers for the study of organelle DNA in plants. Mol Ecol 6: 393-397.

Dunphy BK, Hamrick JL (2005). Gene flow among established Puerto Rican populations of the exotic tree species, Albizia lebbeck. Heredity 94: 418-425.

Ellstrand NC (1992). Gene flow among seed plant populations. New Forests 6: 241-256.

Garcia C, Arroyo JM, Godoy JA, Jordano P (2005). Mating patterns, pollen dispersal, and the ecological maternal neighbourhood in a Prunus mahaleb L. population. Mol Ecol 14: 1821-1830.

Gianfranceschi L, Seglias N, Tarchini R, Komjanc M, Gessler C (1998). Simple sequence repeats for the genetic analysis of apple. Theor Appl Genet 96: 1069-1076.

Godoy JA, Jordano P (2001). Seed dispersal by animals: exact identification of source trees with endocarp DNA microsatellites. Mol Ecol 10: 2275-2283.

Grivet D, Heinze B, Vendramin GG, Petit RJ (2001). Genome walking with consensus primers: application to the large single copy region of chloroplast DNA. Mol Ecol Notes 1: 345-349.

Hardesty BD, Hubbell SP, Bermingham E (2006). Genetic evidence of frequent long-distance recruitment in a vertebrate-dispersed tree. Ecol Lett 9: 516-525.

Hoebee SE, Arnold U, Düggelin C, Gugerli F, Brodbeck S, Rotach $P$ et al. (2007). Mating patterns and contemporary gene flow by pollen in a large continuous and a small isolated population of the scattered forest tree Sorbus torminalis. Heredity 99: 47-55.

Holderegger R, Häner R, Csencsics D, Angelone S, Hoebee SE (2008). S-allele diversity suggests no mate limitation in small populations of a self-incompatible plant. Evolution 62: 2922-2928.

Holderegger R, Wagner HH (2008). Landscape genetics. BioScience 58: 199-207. 
Klein EK, Lavigne C, Gouyon PH (2006). Mixing of propagules from discrete sources at long distance: comparing a dispersal tail to an exponential. BMC Biology 6: 3.

Kramer AT, Ison JL, Ashley MV, Howe HF (2008). The paradox of forest fragmentation genetics. Conserv Biol 22: 878-885.

Kreyer D, Oed A, Walther-Hellwig K, Frankl R (2004). Are forests potential landscape barriers for foraging bumblebees? Landscape scale experiments with Bombus terrestris agg. and Bombus pascuorum (Hymenoptera, Apidae). Biol Conserv 116: 111-118.

Larson BMH, Barrett SCH (2000). A comparative analysis of pollen limitation in flowering plants. Biol J Linn Soc 69: 503-520.

Liebhard R, Gianfranceschi L, Koller B, Ryder CD, Tarchini R, Van de Weg E et al. (2002). Development and characterisation of 140 new microsatellites in apple (Malus $\times$ domestica Borkh.). Mol Breeding 10: 217-241.

Lowe AJ, Boshier D, Ward M, Bacles CFE, Navarro C (2005). Genetic resource impacts of habitat loss and degradation; reconciling empirical evidence and predicted theory for neotropical trees. Heredity 95: 255-273.

Manel S, Schwartz MK, Luikart G, Taberlet P (2003). Landscape genetics: combining landscape ecology and population genetics. Trends Ecol Evol 18: 189-197.

Marshall TC, Slate J, Kruuk LEB, Pemberton JM (1998). Statistical confidence for likelihood-based paternity inference in natural populations. Mol Ecol 7: 639-655.

Meagher T (1986). Analysis of paternity within a natural population of Chamaelirium luteum. 1. Identification of most-likely male parents. Am Nat 128: 199-215.

Mohanty A, Martin JP, Anguinagalde I (2002). Population genetic analysis of European Prunus spinosa (Rosaceae) using chloroplast DNA markers. Am J Bot 89: 1223-1228.

Myers JA, Vellend M, Gardescu S, Marks PL (2004). Seed dispersal by white-tailed deer: implications for long-distance dispersal, invasion, and migration of plants in eastern North America. Oecologia 139: 35-44.

Nason JD, Herre EA, Hamrick JL (1998). The breeding structure of a tropical keystone plant resource. Nature 391: 685-687.

Nathan R (2005). Long-distance dispersal research: building a network of yellow brick roads. Div Distrib 11: 125-130.

Nathan R (2006). Long-distance dispersal of plants. Science 313: 786-788.

Oddou-Muratorio S, Aligon C, Decroocq S, Plomion C, Lamant T, Mush DB (2001). Microsatellite primers for Sorbus torminalis and related species. Mol Ecol Notes 1: 297-299.

Oddou-Muratorio S, Klein EK, Austerlitz F (2005). Pollen flow in the wild service tree, Sorbus torminalis (L.) Crantz. II. Pollen dispersal and heterogeneity in mating success inferred from parent-offspring analysis. Mol Ecol 14: $4441-4452$.

Oddou-Muratorio S, Klein EK, Demesure-Musch B, Austerlitz F (2006). Real-time patterns of pollen flow in the wild service tree, Sorbus torminalis (Rosaceae). III. Mating patterns and the ecological maternal neighborhood. Am J Bot 93: 1650-1659.
Ollerton J, Johnson SD, Hingston AB (2006). Geographical variation in diversity and specificity of pollination. In: Ollerton J, Waser NM (eds). Plant-Pollinator Interactionsfrom Specialization to Generalization. University of Chicago Press: Chicago. pp 283-309.

Raspé O (2001). Inheritance of the chloroplast genome in Sorbus aucuparia L. (Rosaceae). J Hered 96: 507-509.

Raspé O, Findlay C, Jacquemart AL (2000). Biological flora of the British Isles: Sorbus aucuparia L. J Ecol 88: 910-930.

Raspé O, Kohn JR (2002). S-allele diversity in Sorbus aucuparia and Crataegus monogyna (Rosaceae: Maloideae). Heredity 86: 458-465.

Reusch TBH, Wood TE (2007). Molecular ecology of global change. Mol Ecol 16: 3973-3992.

Robertson A, Newton AC, Ennos RA (2004). Multiple hybrid origins, genetic diversity and population genetic structure of two endemic Sorbus taxa on the Isle of Arran, Scotland. Mol Ecol 13: 123-134.

Sang T, Crawford DJ, Stuessy TF (1997). Chloroplast DNA phylogeny, reticulate evolution, and biogeography of Paeonia (Paeoniaceae). Am J Bot 84: 1120-1136.

Slate J, Marshall T, Pemberton J (2000). A retrospective assessment of the accuracy of the paternity inference program CERVUS. Mol Ecol 9: 801-808.

Slavov GT, Howe GT, Gyaourowa AV, Birkes DS, Adams SWT (2005). Estimating pollen flow using SSR markers and paternity exclusion: accounting for mistyping. Mol Ecol 14: 3109-3121.

Sork VL, Nason J, Campbell DR, Fernandez JF (1999). Landscape approaches to historical and contemporary gene flow in plants. Trends Ecol Evol 14: 219-224.

Sork VL, Smouse PE (2006). Genetic analysis of landscape connectivity in tree populations. Land Ecol 21: 821-836.

Steffan-Dewenter I, Kuhn A (2003). Honeybee foraging in differentially structured landscapes. Proc $R$ Soc London 270: 569-575.

Ward M, Dick CW, Gribel R, Lowe AJ (2005). To self or not to self... A review of outcrossing and pollen-mediated gene flow in neotropical trees. Heredity 95: 246-254.

White GM, Boshier DH, Powell W (2002). Increased pollen flow counteracts fragmentation in a tropical dry forest: an example from Swietenia humilis (Zuccarini). Proc Nat Acad Sci USA 99: 2038-2042.

Williams CG, Davis BH (2005). Rate of transgene spread via long-distance seed dispersal in Pinus taeda. Forest Ecol Manage 217: 95-102.

Wohlgemuth T, Bürgi M, Scheidegger C, Schütz M (2002). Dominance reduction of species through disturbance-a proposed management principle for central European forests. Forest Ecol Manage 166: 1-15.

Yamamoto T, Kimura T, Sawamura Y, Manabe T, Kotobuki K, Hayashi T et al. (2002a). Simple sequence repeats for genetic analysis in pear. Euphytica 124: 129-137.

Yamamoto T, Kimura T, Shoda M, Ban Y, Hayashi T, Matsuta N (2002b). Development of microsatellite markers in the Japanese pear (Pyrus pyrifolia Nakai). Mol Ecol Notes 2: 14-16. 